\title{
Prolonged drought stress induced changes in yield and physiological processes of Trifolium repens and Festulolium braunii
}

\author{
M. STANIAK ${ }^{1 *}$, J. BOJARSZCZUK ${ }^{1}$, P. KRASKA $^{2}$, C. KWIATKOWSKI $^{2}$, and E. HARASIM ${ }^{2}$ \\ Department of Forage Crop Production, Institute of Soil Science and Plant Cultivation - State Research Institute, \\ PL-24100 Puławy, Poland ${ }^{1}$ \\ Department of Herbology and Plant Cultivation Techniques, University of Life Sciences in Lublin, \\ PL-20950 Lublin, Poland ${ }^{2}$
}

\begin{abstract}
Water deficit is one of the main environmental factors, and the recognition of plant response to drought stress seems to be crucial for the yield improvement of the important crops. The aim of the study was to investigate the effect of prolonged drought stress on dry matter yield, gas exchange parameters, and relative chlorophyll content in the leaves of Festulolium braunii and Trifolium repens grown in pure stands and in mixture. In the pot experiment, different levels of soil moisture (well-watered conditions and drought stress) and of cultivation method (pure stand and mixture) have been applied. The study has shown that all measured parameters were affected by drought stress. Dry mass yield, net photosynthetic rate $\left(\mathrm{P}_{\mathrm{N}}\right)$, transpiration rate $(\mathrm{E})$, and stomatal conductance were significantly lower under drought stress than under well-watered conditions in all treatment types. T. repens showed the strongest response to stress, whereas F. braunii the weakest when both those species were grown in the pure stand. Under drought conditions, the yield of the mixture was similar to that of F. braunii cultivated in the pure stand, and significantly higher than that of T. repens cultivated in the pure stand. It was also found that under the stress, $\mathrm{P}_{\mathrm{N}}$ and $\mathrm{E}$ of both species in the the mixture was higher than in the pure stand. The highest water use efficiency was observed in F. braunii grown in the mixture. Our research shows, that in regions with limited rainfall, T. repens is more useful for growing in a mixture with $F$. braunii, than in the pure stand.
\end{abstract}

Additional key words: net photosynthetic rate, stomatal conductance, transpiration rate, water-use efficiency, white clover.

\section{Introduction}

The increase in averages of annual air temperature that we have seen in recent years has led to a decrease in the amount of rain and snow, which leads to a deepening of the water deficit, especially during the summer months. Water deficiency in soil affects the metabolism of plants, limits their growth and development, and consequently, decreases their yield (Lipiec et al. 2013, Golldack et al. 2014, Gray and Brady 2016). According to Lisar et al. (2012) water stress can reduce crop yields by up to $50 \%$. Gerten and Rost (2010) report that 2/3 of the world's food production takes place under conditions of water stress. Under these conditions for many grassland areas, drought is likely to increase in importance as a driver of future grassland community structure (Shinoda et al. 2010).

Trifolium repens is one of the most important smallseeded legumes in the world (Frame and Newbould 1986). It is the most important forage legume in the temperate zone and its cultivation can contribute to a more sustainable production system, because it replaces $\mathrm{N}$ mineral fertilization, whose manufacturing and transport cause pollution and consume fossil energy (Elgersma and Schlepers 1997). It is widely used on pasture land in different climatic conditions and soils, showing high ecological plasticity. An important ecological factor limiting the share and yield of T. repens in the sward is its sensitivity to long-term drought (Stypiński 1991, Annicchiarico and Piano 2004). This is due to the specificity of the root system, because $80 \%$ of its mass is located in the $0-20 \mathrm{~cm}$ layer, which dries easily. Under drought conditions, the production of new roots and hairs is also limited (Caradus 1990). Under water deficit conditions, a considerable weakening of Rhizobium activity and worse symbiotic nitrogen fixation, have been observed (Murphy 1988). Legume-grass mixtures are less sensitive to unfavorable environmental conditions, due to differences in the structure of root systems and different

Submitted 3 April 2020, last revision 28 July 2020, accepted 3 August 2020.

Abbreviations: $\mathrm{c}_{\mathrm{i}}$ - intercellular $\mathrm{CO}_{2}$ concentration; DMY - dry mass yield; E - transpiration rate; $\mathrm{FB}$ - Festulolium braunii; $\mathrm{g}_{\mathrm{s}}$ - stomatal conductance; $\mathrm{P}_{\mathrm{N}}$ - net photosynthesis rate; SPAD - relative chlorophyll content in leaves; TR - Trifolium repens; WUE - water use efficiency; YR - agricultural drought index.

* Corresponding author; e-mail: staniakm@iung.pulawy.pl 
environmental requirements of individual components. They have better yield, which is extremely important for the management of permanent grassland. Serajchi et al. (2017) reported, that an ideal forage mixture composed of grasses and legumes has the potential to adopt to a greater range of environmental conditions and may provide a more reliable forage yield with nutritional quality under different environmental conditions. Moreover, in forage mixture, legumes provide $\mathrm{N}$ to accompanying grass through atmospheric $\mathrm{N}$ fixation, which reduces $\mathrm{N}$ fertilizer requirements (Franche et al. 2009). According to Wilkins et al. (1998), the widespread use of small-seeded legumes in feed production in the northern part of the European Union will allow saving fertilizers.

The cultivation of legume-grass mixtures, which are a valuable source of protein in animal nutrition and enable the production of fodder under conditions of low $\mathrm{N}$ fertilization, is particularly important under sustainable farming. Amajor role in this respect is attributed to T. repens, which gives a high yield in the mixture with Festulolium braunii giving high quality fodder (Olszewska 2008). F. braunii is an intergeneric hybrid formed from Festuca pratensis and Lolium multiflorum. It is characterized by a high yield potential, similar to L. multiflorum, and its more developed root system contributes to better durability and wintering, similar to F. pratensis (Šimkūnas et al. 2009, Østrem et al. 2013). However, studies on the cultivation of $T$. repens in the mixture with $F$. braunii are scarce and require further investigation, especially under drought stress conditions. It is known that hybrids can be a valuable source of variability for increasing resistance to abiotic and biotic stresses (Perlikowski et al. 2014, 2019). According to Saeidnia et al. (2017), conducting research on the tolerance of crops to water stress based on the reduction of dry matter yield under drought conditions compared to optimal conditions is of great diagnostic value, especially in the context of breeding programs.

Photosynthetic apparatus is the most stress-sensitive and is the first responding to any changes in the environment (Fang and Xiong 2015). The gas exchange rate depends on many environmental factors such as: irradiance, temperature, $\mathrm{O}_{2}$ and $\mathrm{CO}_{2}$ concentrations, water availability, and also on a number of internal factors such as: leaf structure, chlorophyll content, accumulation of photosynthetic products, enzyme activities, mineral supply, or physiological age of leaves (Kalaji and Łoboda 2010). It generally differs also in different development stages, beeing the highest during the flowering period and the lowest during seed development. Drought has an inhibitory effect on photosynthesis and this may be associated with low $\mathrm{CO}_{2}$ availability, due to the limitation of its diffusion through the stomata (Flexas and Medrano 2002, Lawlor 2002, Perlikowski et al. 2016). The first symptoms of wilting usually appear in older leaves, where photosynthesis is reduced and translocation of assimilates is inhibited (Akhtar and Nazir 2013). According to Kacperska (2004), inhibition of photosynthesis is one of the plant dysfunctions that has a high diagnostic value and can be a way of assessing the plant's response to stress.

The net photosynthetic rate is closely related to the chlorophyll content in leaves (Kura-Hotta et al. 1987, Croft et al. 2017). Kozłowski et al. (2001) reported that chlorophyll can be also considered an indicator of the annual grass yield and grass regrowth, because there is a positive correlation between its content in grass leaf blades and dry matter yield. The content of this pigment in leaves is a characteristic feature of species and even of the cultivar, but also depends on many external factors such as: type of soil, weather conditions, and availability of nutrients (Loka et al. 2018).

This research was conducted to investigate the effect of prolonged drought stress on dry matter yield, gas exchange parameters, and relative chlorophyll content of $T$. repens and $F$. braunii grown in pure stands and in mixture.

\section{Materials and methods}

Plants and growth conditions: Pot experiment was conducted in the greenhouse of the Institute of Soil Science and Plant Cultivation - State Research Institute in Puławy, in Poland [ $\left.51^{\circ} 24^{\prime} 59^{\prime \prime} \mathrm{N}, 21^{\circ} 58^{\prime} 9^{\prime \prime} \mathrm{E}\right]$. The experiment was conducted by completely randomized block method, in four replications. Festulolium braunii (K. Richt. A. Camus) cv. Felopa (FB) and Trifolium repens $(\mathrm{L}.) \mathrm{cv}$. Romena (TR) were grown in pure stands and in the mixture $(50 \% \mathrm{FB}+50 \% \mathrm{TR})$ (MX). Seeds were sown in Mitcherlich pots containing $7 \mathrm{~kg}$ of soil. For all treatments, 20 seeds were planted and following emergence plants were thinned to 8 per pot (in mixture $-4 \mathrm{FB}$ and $4 \mathrm{TR})$. Pots were filled with light silty loam $(0-30 \mathrm{~cm})$ mixed with sand in 5:2 ratio. The content of available nutrients was as follows (mg per $100 \mathrm{~g}$ soil): $\mathrm{P}$ 24.8, $\mathrm{K}-14.2$ and $\mathrm{Mg}-2.2$, soil $\mathrm{pH}$ in $1 \mathrm{~mol} \mathrm{KCl}$ was 7.4. Plants were fertilized at doses $\left(\mathrm{g} \cdot \mathrm{pot}^{-1}\right): 0.5 \mathrm{~N}, 1.0 \mathrm{P}, 1.5 \mathrm{~K}$, and $0.5 \mathrm{Mg}$ in the form of solutions: $\mathrm{NH}_{4} \mathrm{NO}_{3}, \mathrm{KH}_{2} \mathrm{PO}_{4}$, $\mathrm{K}_{2} \mathrm{SO}_{4}$, and $\mathrm{MgSO}_{4} \cdot 7 \mathrm{H}_{2} \mathrm{O}$ before sowing and $0.5 \mathrm{~N}$ after each cutting of grass in pure stand and half of this dose after each cutting of mixture. Trifolium repens in the pure stand was not fertilized by nitrogen (except for the start dose). The $\mathrm{K}$ dose was divided into two parts; one part was used in spring and the other after second cut. In each year, microelements nutrient solution was applied in spring.

Water treatment began 8 weeks after sowing (first year), and in the second and third year of growing - 2 weeks after starting of vegetation. There were two different irrigation treatments: $70 \%$ field water capacity (FWC) as wellwatered conditions and $40 \% \mathrm{FWC}$ as a drought stress. The capillary capacity of the soil was determined in Vanschaffe cylinders. The water treatments were stopped after last cut and plants were watered as needed. The pots were outside during day and during night and rain they were inside the greenhouse.

Methods and measurements: Gas exchange parameters: net photosynthetic rate $\left(\mathrm{P}_{\mathrm{N}}\right)$, transpiration rate $(\mathrm{E})$, stomatal conductance $\left(\mathrm{g}_{\mathrm{s}}\right)$, and intercellular $\mathrm{CO}_{2}$ concentration $\left(\mathrm{c}_{\mathrm{i}}\right)$ were measured three times in the first year and four times in the second and third year of growing. Water use efficiency (WUE) was calculated as a ratio of light 
saturated $\mathrm{P}_{\mathrm{N}}$ to $\mathrm{E}\left(\mathrm{P}_{\mathrm{N}} / \mathrm{E}\right)$. These parameters $\left(\mathrm{P}_{\mathrm{N}}, \mathrm{E}, \mathrm{g}_{\mathrm{s}}, \mathrm{c}_{\mathrm{i}}\right)$ were measured one day before each cut with the CIRAS-2 Portable Photosynthesis System (PP Systems Internatinal, Amesbury, MA, USA). Leaf gas exchange parameters were measured between 7:00 - 11:00, on the young, fully exposed leaves in six replications, operating at $390 \mu \mathrm{mol} \mathrm{mol}{ }^{-1}$ ambient $\mathrm{CO}_{2}$ concentration, an irradiance of $1000-1200 \mu \mathrm{mol} \mathrm{m} \mathrm{m}^{-2} \mathrm{~s}^{-1}$ of photosynthetic active radiation, a temperature of $17-25^{\circ} \mathrm{C}$, a chamber flow rate of $200 \mathrm{ml} \mathrm{min}^{-1}$, and a relative humidity of $50 \%$. Relative chlorophyll content (SPAD index) was measured in the same scheme as gas exchange parameters with a SPAD 502 (Minolta, Tokyo, Japan) chlorophyll meter in four replications. This device measures the difference between light absorption at wavelength of 650 and $940 \mathrm{~nm}$, and the quotient of these values is presented as leaf greenness, i.e. indexed chlorophyll content (Blackmer and Schepers 1994). The result is given in the SPAD (Soil and Plant Analysis Development) units in the range from 0 to 800 . Measurements were taken at weekly intervals throughout the growing season of the plants (30 leaves were measured in each pot).

Plant material was collected three times during the first growing season, and four times during second and third vegetation year. Harvest was carried out at the beginning of $T$. repens flowering. Dry matter was obtained by drying samples in a ventilated oven at $70{ }^{\circ} \mathrm{C}$ until constant mass. Dry mass yield (DMY) and agricultural drought index (YR) were evaluated. The YR determining yield reductions due to water shortage in the soil, was calculated according to the formula (Labędzki 2006): $Y R=1-\left(Y_{\mathrm{re}} / Y_{\mathrm{p}}\right)$, where $Y_{r e}$ is the yield reduced due to soil water deficit, and $Y_{p}$ is the potential yield under optimal soil moisture.

Statistical analysis: The presented data are the mean values from the years 2012 - 2014, as a result of the similar reaction of the plants examined to different soil moisture and cultivation method uncovered during three year study. The results were statistically analyzed with the use of the analysis of variance (ANOVA) for the completely randomized design, using Statistica v.10.0 software. Tukey's multiple comparison test was used to compare differences between the means for main effects (factors: water regime and treatment), whereas confidence intervals for the means of least significant difference $(\alpha=0.05)$ were used to compare means from subclasses (interactions).

\section{Results}

The effect of the main factors, such as water regimes (W) and treatments $(\mathrm{T})$ as well as the interaction $\mathrm{W} \times \mathrm{T}$, on dry mass yield (DMY) was significant $(P<0.05)$ in all years (Table 1). Drought stress resulted in a significant decrease in the annual DMY of the tested plants in all years of the study and total yields, as compared to well-watered conditions, regardless of the species and cultivation method (Table 1). The highest yield reduction occurred in the first year of growing season (by $35.1 \%$ ), lower in the second year (by $26.5 \%$ ), and the lowest in the third year (by $17.2 \%$ ). The most drought sensitive was T. repens cultivated in pure stand, which showed the highest DMY decrease under drought conditions (in subsequent years by $47.7,47.8$, and $32.0 \%$, respectively, total yield by $41.9 \%$ ) (Fig. 1). Cultivation of $T$. repens in a mixture with $F$. braunii contributed to a significantly lower DMY reduction under stress conditions (by $37.8,23.8$, and $3.4 \%$ respectively, total yield by $24.8 \%$ ). The most resistant to drought was $F$. braunii cultivated in pure stand, which only in the third year of growing season showed a significant decrease in DMY under soil water deficit (by $12.3 \%$ ). Fig. 2 shows a comparison of biomass of $T$. repens, $F$. braunii, and mixtures under well-watered conditions and drought stress in the third year of growing. Taking into account the total DMY for the three-year period, T. repens cultivated in pure stand under well-watered conditions gave the highest yields, and under drought stress the lowest. The DMY of $F$. braunii cultivated in pure stand and

Table 1. Mean values of dry mass yield (DMY) $\left[\mathrm{g} \mathrm{pot}^{-1}\right]$ as affected by water regime (W) and cultivation method (a pure stand or a mixture, T). WW - average DMY of tested plants (regardless of species and cultivation method) under well-watered conditions, DS - average DMY of tested plants (regardless of species and cultivation method) under drought stress, TR - Trifolium repens, FB Festulolium braunii, MX - mixture, first year - sum of three cuts, second and third year - sum of four cuts, total DMY - sum of three years. Means \pm SDs, $n=4$. Different letters indicate significant difference according to Tukey's test, $P<0.05$.

\begin{tabular}{|c|c|c|c|c|c|c|c|c|}
\hline Water regime $(\mathrm{W})$ & \multicolumn{2}{|c|}{ DMY first year } & \multicolumn{2}{|c|}{ DMY second year } & \multicolumn{2}{|c|}{ DMY third year } & \multicolumn{2}{|c|}{ Total DMY } \\
\hline WW & \multicolumn{2}{|c|}{$57.8 \pm 12.6 b$} & \multicolumn{2}{|c|}{$83.5 \pm 8.1 b$} & \multicolumn{2}{|c|}{$77.2 \pm 17.0 \mathrm{~b}$} & \multicolumn{2}{|c|}{$218.5 \pm 21.5 b$} \\
\hline DS & \multicolumn{2}{|c|}{$37.5 \pm 4.0 \mathrm{a}$} & \multicolumn{2}{|c|}{$61.4 \pm 13.8 \mathrm{a}$} & \multicolumn{2}{|c|}{$63.9 \pm 10.4 \mathrm{a}$} & \multicolumn{2}{|c|}{$162.7 \pm 19.5 \mathrm{a}$} \\
\hline \multicolumn{9}{|l|}{ Treatment $(\mathrm{T})$} \\
\hline TR & \multicolumn{2}{|c|}{$51.7 \pm 17.8 b$} & \multicolumn{2}{|c|}{$64.0 \pm 22.5 \mathrm{a}$} & \multicolumn{2}{|c|}{$74.5 \pm 7.6 b$} & \multicolumn{2}{|c|}{$190.2 \pm 55.4 \mathrm{a}$} \\
\hline FB & \multicolumn{2}{|c|}{$39.3 \pm 2.7 a$} & \multicolumn{2}{|c|}{$74.5 \pm 5.1 b$} & \multicolumn{2}{|c|}{$73.0 \pm 16.3 \mathrm{ab}$} & \multicolumn{2}{|c|}{$186.7 \pm 11.8 \mathrm{a}$} \\
\hline MX & \multicolumn{2}{|c|}{$51.9 \pm 13.5 b$} & \multicolumn{2}{|c|}{$78.9 \pm 12.5 b$} & \multicolumn{2}{|c|}{$64.2 \pm 8.7 \mathrm{a}$} & \multicolumn{2}{|c|}{$194.9 \pm 29.3 \mathrm{a}$} \\
\hline$A N O V A$ summary & $F$-ratio & $P$ & $F$-ratio & $P$ & $F$-ratio & $P$ & $F$-ratio & $P$ \\
\hline $\mathrm{W}$ & 171.66 & 0.000 & 78.35 & 0.000 & 24.03 & 0.000 & 161.29 & 0.000 \\
\hline $\mathrm{T}$ & 28.98 & 0.000 & 12.42 & 0.000 & 27.00 & 0.000 & 1.32 & 0.292 \\
\hline $\mathrm{W} \times \mathrm{T}$ & 29.04 & 0.000 & 16.43 & 0.000 & 5.53 & 0.013 & 28.22 & 0.000 \\
\hline
\end{tabular}




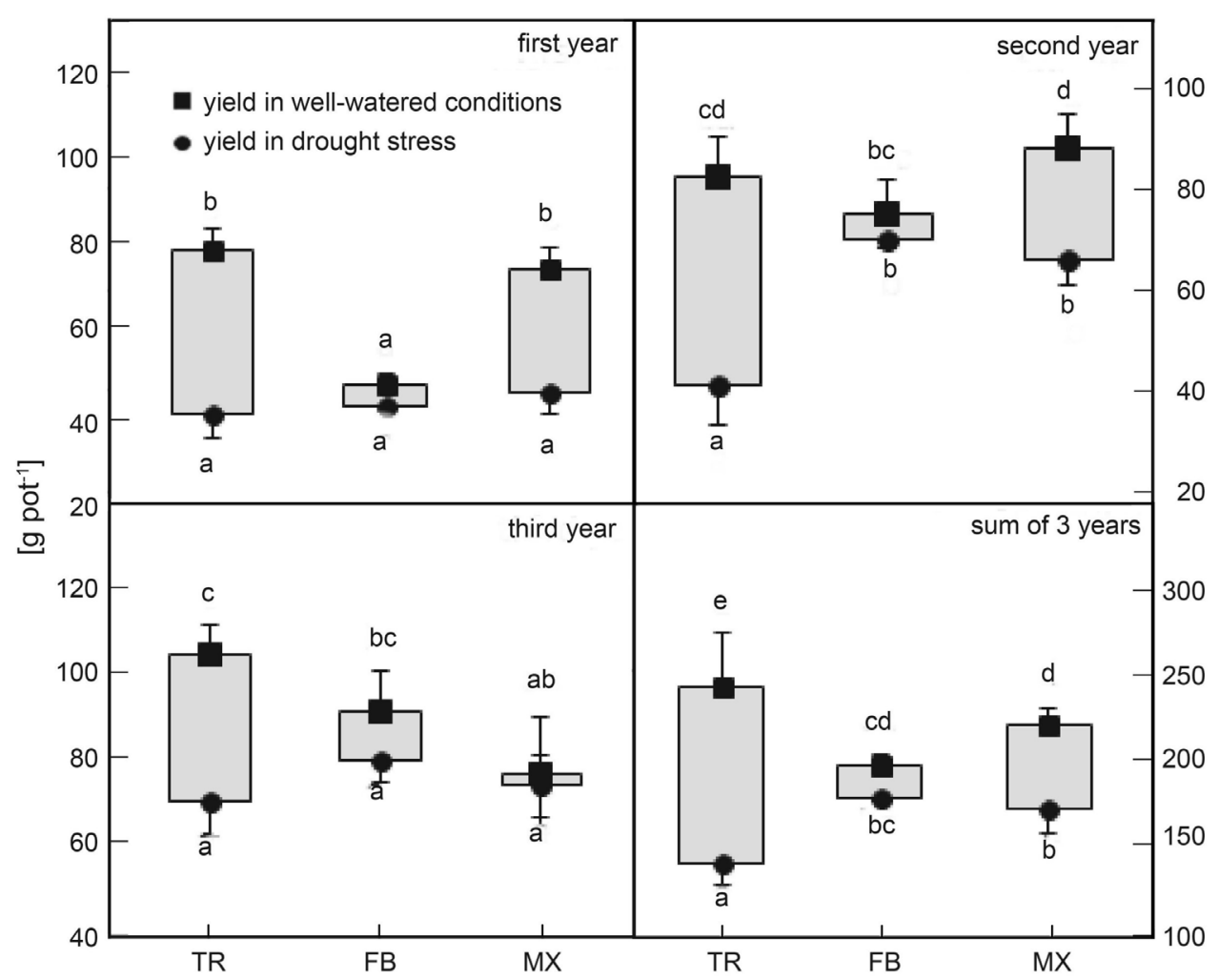

Fig. 1. The decrease of dry matter yield of Trifolium repens and Festulolium braunii grown in a pure stand and in a mixture under different water regimes. TR - T. repens in pure stand, FB - F. braunii in pure stand, MX - mixture; first year - sum of three cuts, second and third year - sum of four cuts. Means \pm SDs, $n=4$; different letters represent significant differences among treatments (Tukey's test, $P<0.05)$.
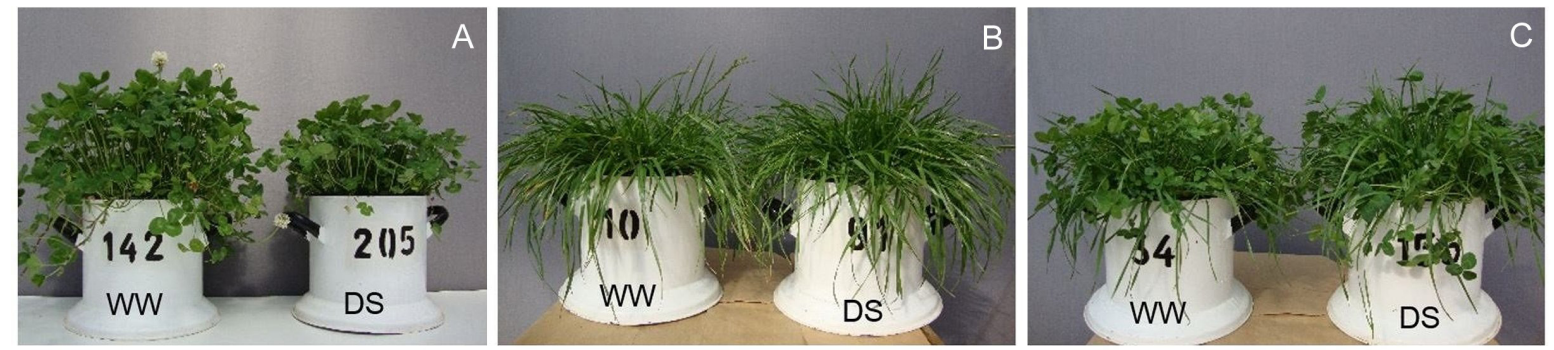

Fig. 2. Trifolium repens $(A)$, Festulolum braunii $(B)$, and their mixture $(C)$ under well-watered conditions (WW) and drought stress (DS) in the third year of growing.

DMY of mixture were similar and significantly higher than DMY of T. repens in pure stand under water stress. The reduction of DMY of $T$. repens and F. braunii, expressed by the agricultural drought index, remained within the limits from 0.104 to 0.477 in the first year, from 0.065 to 0.478 in the second, and from 0.034 to 0.320 in the third year of growing (Fig. 3). The highest values of YR index in all years were found in pure stand of $T$. repens, while the lowest in F. braunii in the first and second year, and in the mixture in the third year of growing.

An important factor affecting the yield of plants is their gas exchange. The soil water deficiency caused significant decrease in $\mathrm{P}_{\mathrm{N}}, \mathrm{E}, \mathrm{g}_{\mathrm{s}}, \mathrm{c}_{\mathrm{i}}$, in average by 6.1 , $10.9,19.7$, and $5.4 \%$ respectively, regardless of the species and cultivation method (Table 2). Moreover, T. repens exhibited significantly higher $\mathrm{P}_{\mathrm{N}}, \mathrm{E}$, and $\mathrm{g}_{\mathrm{s}}$ than
F. braunii, irrespective of soil moisture and cultivation method. T. repens showed the highest $\mathrm{P}_{\mathrm{N}}$ under wellwatered conditions, regardless of the cultivation method, but under drought conditions, its $\mathrm{P}_{\mathrm{N}}$ was significantly higher when cultivated in mixture (Fig. 4A). F. braunii showed significantly higher $\mathrm{P}_{\mathrm{N}}$ when grown in a mixture both in well-watered conditions and during drought stress. The lowest $\mathrm{P}_{\mathrm{N}}$ in both $T$. repens and $F$. braunii cultivated in pure stand, regardless of the water conditions, was observed in the first year of growing - 8.5 and $6.6 \mu \mathrm{mol}\left(\mathrm{CO}_{2}\right) \mathrm{m}^{-2} \mathrm{~s}^{-1}$, respectively, higher in the second year -10.8 and $8.4 \mu \mathrm{mol}\left(\mathrm{CO}_{2}\right) \mathrm{m}^{-2} \mathrm{~s}^{-1}$, and the highest in the third year -15.0 and $12.2 \mu \mathrm{mol}\left(\mathrm{CO}_{2}\right) \mathrm{m}^{-2} \mathrm{~s}^{-1}$. The soil moisture did not significantly affect $\mathrm{E}$ of $T$. repens and $F$. braunii grown in pure stands, but significantly reduced it when these species were grown in a mixture (Fig. $4 B$ ). 


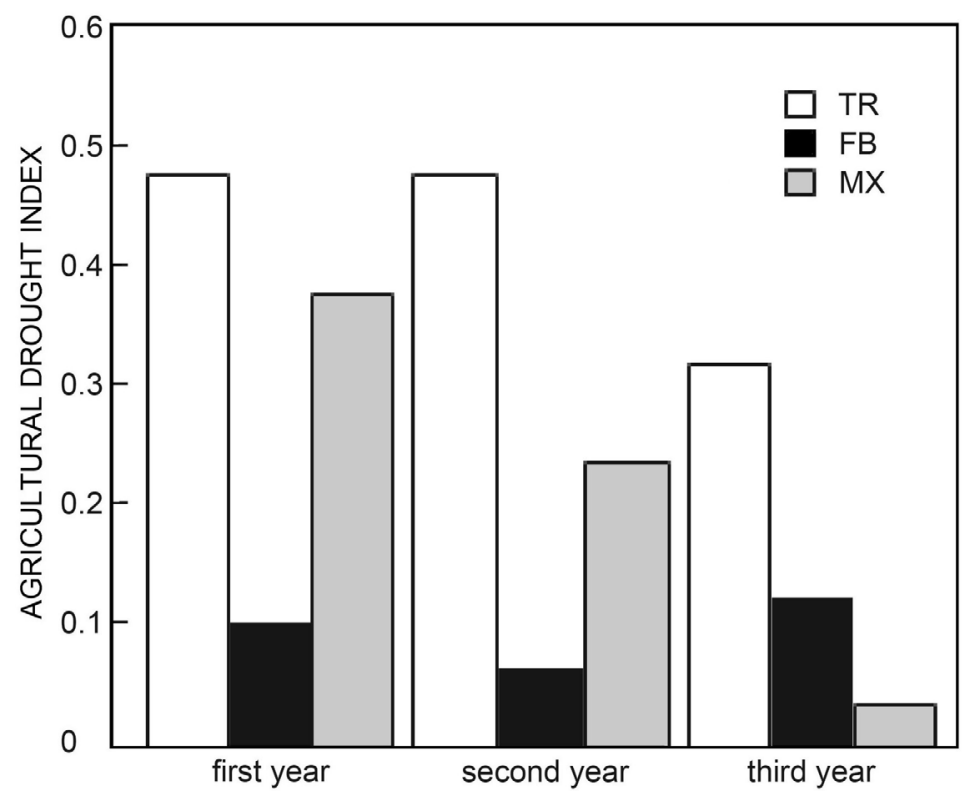

Fig. 3. Agricultural drought index for Trifolium repens, Festulilum braunii, and their mixture in subsequent growing years. TR - $T$. repens in a pure stand, FB - F. braunii in a pure stand, MX - mixture.

Table 2. Mean values over three years of net photosynthetic rate $\left(\mathrm{P}_{\mathrm{N}}\right)\left[\mu \mathrm{mol}\left(\mathrm{CO}_{2}\right) \mathrm{m}^{-2} \mathrm{~s}^{-1}\right]$, transpiration rate $(\mathrm{E})\left[\mathrm{mmol}\left(\mathrm{H}_{2} \mathrm{O}\right) \mathrm{m}^{-2}\right.$ $\mathrm{s}^{-1}$, stomatal conductance $\left(\mathrm{g}_{\mathrm{s}}\right)$ [ $\mathrm{mmol}\left(\mathrm{H}_{2} \mathrm{O}\right) \mathrm{m}^{-2} \mathrm{~s}^{-1}$, intercellular $\mathrm{CO}_{2}$ concentration $\left(\mathrm{c}_{\mathrm{i}}\right)$ [ $\mu \mathrm{mol} \mathrm{mol}^{-1}$, water use efficiency (WUE) $\left[\mu \mathrm{mol}\left(\mathrm{CO}_{2}\right) \mathrm{mmol}\left(\mathrm{H}_{2} \mathrm{O}\right)^{-1}\right]$, and relative chlorophyll content (SPAD index) for different water regimes (W) and cultivation methods (T). WW - average traits of tested plants (regardless of species and cultivation method) under well-watered conditions, DS - average traits of tested plants (regardless of species and cultivation method) under drought stress, TR-ps - Trifolium repens in pure stand, FB-ps Festulolium braunii in pure stand, TR-mx - T. repens in mixture, FB-mx $-F$. braunii in mixture. Means \pm SDs, $n=6$. Different letters indicate significant difference according to Tukey's test, $P<0.05$.

\begin{tabular}{|c|c|c|c|c|c|c|c|c|c|c|c|}
\hline Water regime $(\mathrm{W})$ & $\mathrm{P}_{\mathrm{N}}$ & \multicolumn{2}{|l|}{$\mathrm{E}$} & \multicolumn{2}{|l|}{$\mathrm{g}_{\mathrm{s}}$} & \multicolumn{2}{|l|}{$\mathrm{c}_{\mathrm{i}}$} & \multicolumn{2}{|l|}{ WUE } & \multicolumn{2}{|l|}{ SPAD } \\
\hline WW & $11.18 \pm 1.65 b$ & \multicolumn{2}{|c|}{$3.12 \pm 0.36 b$} & \multicolumn{2}{|c|}{$293.5 \pm 57.6 b$} & \multicolumn{2}{|c|}{$243.2 \pm 7.4 b$} & \multicolumn{2}{|c|}{$3.81 \pm 0.37 \mathrm{a}$} & \multicolumn{2}{|c|}{$439.6 \pm 56.2 \mathrm{a}$} \\
\hline DS & $10.15 \pm 1.28 \mathrm{a}$ & \multicolumn{2}{|c|}{$2.78 \pm 0.24 a$} & \multicolumn{2}{|c|}{$235.6 \pm 38.9 \mathrm{a}$} & \multicolumn{2}{|c|}{$230.1 \pm 12.4 \mathrm{a}$} & \multicolumn{2}{|c|}{$3.92 \pm 0.39 \mathrm{a}$} & \multicolumn{2}{|c|}{$476.7 \pm 66.0 \mathrm{~b}$} \\
\hline \multicolumn{12}{|l|}{ Treatment $(\mathrm{T})$} \\
\hline TR-ps & $11.45 \pm 1.07 \mathrm{c}$ & \multicolumn{2}{|c|}{$3.06 \pm 0.27 b$} & \multicolumn{2}{|c|}{$275.5 \pm 48.1 b$} & \multicolumn{2}{|c|}{$234.5 \pm 11.9 \mathrm{a}$} & \multicolumn{2}{|c|}{$3.98 \pm 0.36 b c$} & \multicolumn{2}{|c|}{$516.8 \pm 53.1 b$} \\
\hline TR-mx & $12.31 \pm 0.85 \mathrm{~d}$ & \multicolumn{2}{|c|}{$3.16 \pm 0.30 \mathrm{~b}$} & \multicolumn{2}{|c|}{$299.8 \pm 57.7 c$} & \multicolumn{2}{|c|}{$234.8 \pm 14.9 \mathrm{a}$} & \multicolumn{2}{|c|}{$4.17 \pm 0.25 c$} & \multicolumn{2}{|c|}{$502.1 \pm 36.3 b$} \\
\hline FB-ps & $9.05 \pm 0.39 \mathrm{a}$ & \multicolumn{2}{|c|}{$2.75 \pm 0.25 \mathrm{a}$} & \multicolumn{2}{|c|}{$222.1 \pm 31.4 \mathrm{a}$} & \multicolumn{2}{|c|}{$240.9 \pm 10.9 \mathrm{a}$} & \multicolumn{2}{|c|}{$3.41 \pm 0.24 \mathrm{a}$} & \multicolumn{2}{|c|}{$399.2 \pm 21.0 \mathrm{a}$} \\
\hline FB-mx & $9.85 \pm 0.45 b$ & $2.83 \pm$ & $.35 \mathrm{a}$ & $260.8 \pm$ & $62.4 \mathrm{~b}$ & $236.3 \pm$ & $10.9 \mathrm{a}$ & $3.91 \pm$ & $39 b$ & $414.5 \pm$ & $28.8 \mathrm{a}$ \\
\hline ANOVA summary & $F$-ratio $P$ & $F$-ratio & $P$ & $F$-ratio & $P$ & $F$-ratio & $P$ & $F$-ratio & $P$ & $F$-ratio & $P$ \\
\hline $\mathrm{W}$ & $30.27 \quad 0.000$ & 23.79 & 0.000 & 41.36 & 0.000 & 18.10 & 0.000 & 1.61 & 0.211 & 10.28 & 0.003 \\
\hline $\mathrm{T}$ & $94.47 \quad 0.000$ & 10.10 & 0.000 & 12.53 & 0.000 & 0.57 & 0.641 & 8.18 & 0.000 & 26.81 & 0.000 \\
\hline $\mathrm{W} \times \mathrm{T}$ & $3.78 \quad 0.017$ & 2.41 & 0.049 & 3.52 & 0.023 & 0.97 & 0.416 & 2.71 & 0.050 & 0.41 & 0.750 \\
\hline
\end{tabular}

The highest $\mathrm{g}_{\mathrm{s}}$ under well-watered conditions was found in T. repens, regardless of the cultivation method, and in $F$. braunii grown in the mixture. Under stress conditions, T. repens showed significantly lower values of $\mathrm{g}_{\mathrm{s}}$ in pure stand, while $F$. braunii exhibited significantly lower $\mathrm{g}_{\mathrm{s}}$ in mixture (Fig. 4C). The water use efficiency under drought conditions was significantly higher only in $F$. braunii grown in a mixture, which proved the most effective water management in this type of cultivation (Fig. 4D).

A significantly higher SPAD index was found in $T$. repens than in F. braunii, irrespective of cultivation method and soil moisture conditions (Table 2). Higher
SPAD indexes were also recorded under stress conditions, irrespective of the species and cultivation method. However, no interaction between the main experimental factors and the SPAD index was detected.

\section{Discussion}

Drought stress reduces crop yield, which is a major agricultural problem. The growth inhibition of plants is accompanied by reduced export of assimilates from leaf blades to other organs and disturbances in their transport 


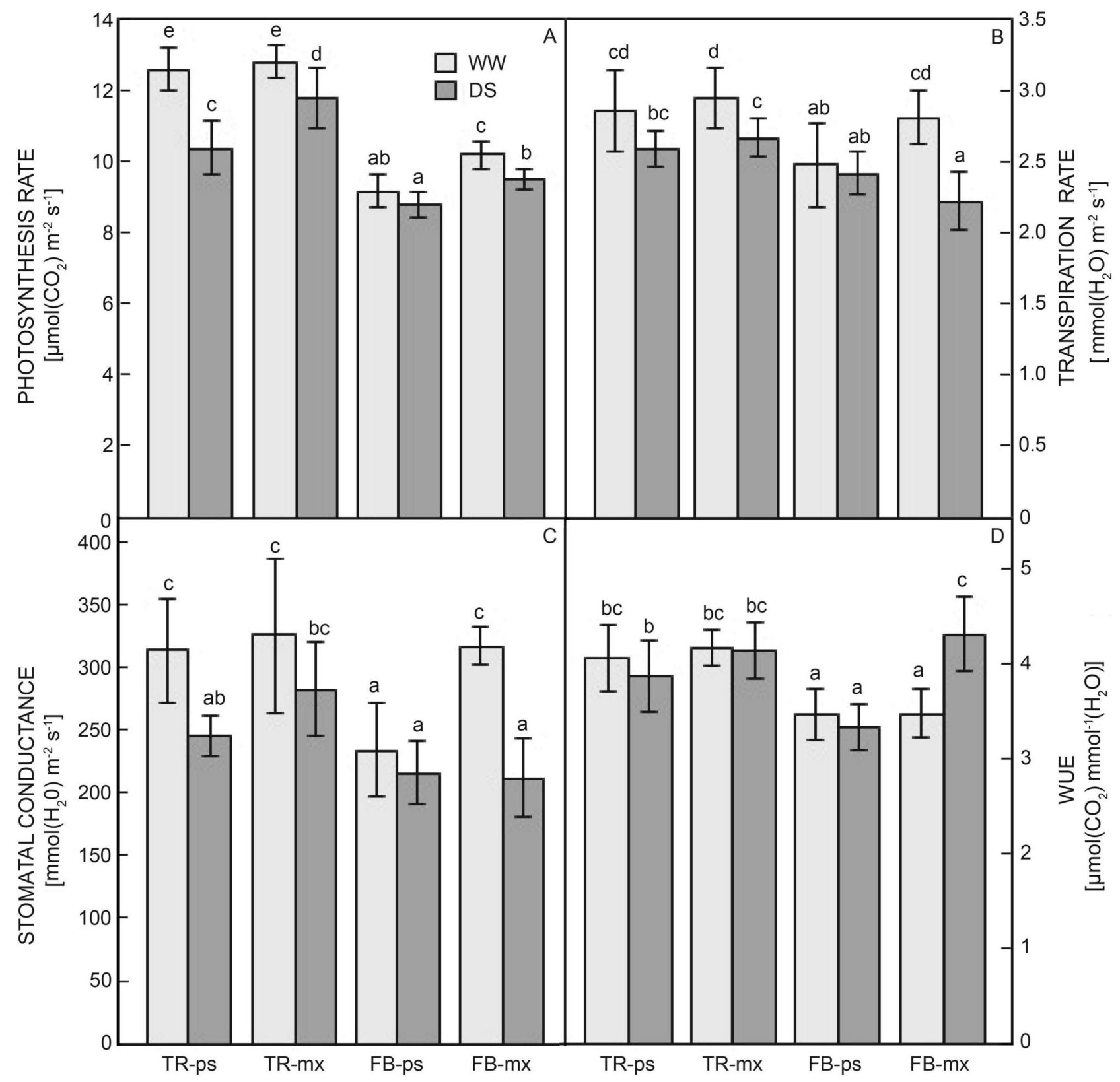

Fig. 4. Mean values over three years of net photosynthetic rate $\left(\mathrm{P}_{\mathrm{N}}\right)\left[\mu \mathrm{mol}\left(\mathrm{CO}_{2}\right) \mathrm{m}^{-2} \mathrm{~s}^{-1}\right]$, transpiration rate $(\mathrm{E})\left[\mathrm{mmol}\left(\mathrm{H}_{2} \mathrm{O}\right) \mathrm{m}^{-2} \mathrm{~s}^{-1}\right]$, stomatal conductance $\left(\mathrm{g}_{\mathrm{s}}\right)\left[\mathrm{mmol}\left(\mathrm{H}_{2} \mathrm{O}\right) \mathrm{m}^{-2} \mathrm{~s}^{-1}\right]$, and water use efficiency (WUE) $\left[\mu \mathrm{mol}\left(\mathrm{CO}_{2}\right) \mathrm{mmol}\left(\mathrm{H}_{2} \mathrm{O}\right)^{-1}\right]$ for different water regimes and cultivation methods of Trifolium repens and Festulolium braunii grown in a pure stand and in a mixture. TR-ps - T. repens in pure stand, FB-ps - F. braunii in pure stand, TR-mx - T. repens in mixture, FB-mx - F. braunii in mixture. WW - plants growing under wellwater conditions, DS - plants growing under drought stress. Means \pm SDs, $n=6$; different letters represent significant differences among treatments (Tukey's test, $P<0.05$ ).

and distribution (Lu and Zhang 1998). The results of our research confirmed a significant decrease in DMY of $T$. repens and F. braunii in response to water stress, regardless of the cultivation method. T. repens growing in pure stand was the most stress-sensitive. Cultivation of this species in a mixture contributed to a smaller reduction in yield under drought stress, which indicated greater suitability of mixtures for cultivation in areas with limited rainfall. Higher yield potential of legume-grass mixtures under drought conditions, compared to pure legume stands, has also been found in the studies on mixtures of Medicago lupulina with Lolium perenne (Küchenmeister et al. 2013), and in the previous studies related to mixtures of Medicago $\times$ varia with $F$. braunii (Staniak et al. 2018) and Trifolium pratense with $F$. braunii (Staniak et al. 2019). These studies also showed that legumes and $F$. braunii cultivated in a pure stand and in a mixture have a higher decrease in total yield in drought conditions in the first year of growing, than in the second and third year. It is related to the lower photosynthesis in the first year than 
in the following years and probably due to plant adaptation to drought conditions, which was confirmed in the current research.

Inhibition of plant growth in dry conditions is a defensive response of the plants. A water shortage in the soil reduces the water potential of shoots and stimulates the growth of roots. A direct reflection of these reactions in the plant is a change in the distribution of assimilates, resulting in a lower yield (Farooq et al. 2009, Blum 2011). In our research, the most resistant to long-term stress was $F$. braunii growing in pure stand. Fodder grasses have a more developed and deeper root system than T. repens, so their resistance to drought is relatively higher. This was revealed by Skinner and Comas (2010) who showed, that drought stress significantly increase the proportion of deep roots for grasses, but has no effect on the proportion of deep roots for legume. An extensive root system and the availability of root distribution at deeper soil layers during drought stress plays an important role in the persistence and drought tolerance of plants (Gewin 2010, Sokolovic et al. 2013).

The negative effect of drought on the DMY might be due to the key role of water in physiological processes, like photosynthetic rate, which affects plant dry mass production (Abdalla and El-Khoshiban 2007). Our research showed that water stress reduced the $\mathrm{P}_{\mathrm{N}}$ and $\mathrm{E}$ of $T$. repens and $F$. braunii, but the cultivation method was important. Both species growing in the mixture assimilated $\mathrm{CO}_{2}$ more intensively and limited transpiration to a more extent than in pure stands. Olszewska (2008) demonstrated a higher $\mathrm{P}_{\mathrm{N}}$ in $F$. braunii when it was grown in mixture with $T$. repens (by $49 \%$ ) and Lotus corniculatus (by $24 \%$ ), compared to pure stands. Other studies confirmed the negative impact of soil water deficit on $\mathrm{P}_{\mathrm{N}}, \mathrm{E}$, and $\mathrm{g}_{\mathrm{s}}$ in T. repens (Grieu et al. 1993), T. pratense (Staniak et al. 2019), Medicago $\times$ varia (Staniak et al. 2018), F. braunii, L. multiflorum, F. pratensis, Dactylis glomerata (Staniak and Kocon 2015). The reduction in $\mathrm{P}_{\mathrm{N}}$ due to water scarcity in the soil is most likely associated with decrease in RuBisCo activity and decrease in the the availability of $\mathrm{CO}_{2}$ in the intercellular spaces due to decreased $g_{\mathrm{s}}$ (Jones 1998, Lu and Zhang 1998, Hura et al. 2007, Galmes et al. 2011). Stomata control the access of $\mathrm{CO}_{2}$ to the mesophyll and the diffusion of water vapour between a leaf and an environment and positive correlation between leaf water potential and stomatal conductance has been suggested (Hepworth et al. 2015). A large reduction in the $\mathrm{P}_{\mathrm{N}}$ in grasses may also be a result of the increased share of photorespiration in the gas exchange, which in dry conditions is one of the energy dissipation mechanisms (Flexas and Medrano 2002).

Water use efficiency is often used to describe the relationship between plant yield and water consumption, and its magnitude can reflect the ability of plants to adapt to arid environments (Peng et al. 2011). It is dependent on the $\mathrm{P}_{\mathrm{N}}$ and $\mathrm{E}$ under specific conditions. The highest WUE under drought conditions was found in $F$. braunii cultivated in a mixture, which indicated economical water management under unfavorable conditions. Other studies also showed a significantly higher WUE in F. braunii growing in the mixture with $T$. repens and $L$. corniculatus, compared to pure stands (Olszewska 2008). According to Hall (1990), a high WUE allows maintaining a high plant yield rate even during drought. In turn, Blum (2009) noticed, that WUE is not associated with drought resistance, as some species resistant to drought show low WUE, which is associated with a deeper root system and higher use of water. According to this author, the increase in crop yield under drought conditions is closely connected with the growth and development of the root system, especially at the beginning of the growing season.

The direct use of leaf chlorophyll content has a physiological basis due to the inherent dependence of photosynthesis on chlorophyll molecules as the primary means of harvesting light energy to drive electron transport reactions (Croft et al. 2017, Kosmala et al. 2012). The chlorophyll content in leaves varies among species and cultivars, but also depends on soil and climate conditions, availability of nutrients, and development stage of plants (Loka et al. 2018). The results of our research showed the increase in SPAD index in T. repens and $F$. braunii under drought conditions, which was confirmed by research of other authors indicating a similar response of legume plants T. repens, L. corniculatus (Olszewska 2008) and fodder grasses $F$. braunii, D. glomerata, F. pratensis, L. multiflorum (Staniak and Kocoń 2015) to drought. Rising chlorophyll content with declining water supply may be associated with a decrease in leaf area and an increase in leaf thickness and chloroplast density in stressed plants (Dastborhan and Ghassemi-Golezani 2015). This could be a defensive response to reduce the harmful effects of drought stress (Farooq et al. 2009). Increasing chlorophyll content under stress condition could help leaves to cope with environmental stress and to compensate for any damage that could affect the integrity and function of the photosynthetic system.

In summary, our analysis clearly showed that reactions to water deficit, including dry matter yield, gas exchange parameters, and relative chlorophyll content were different in $T$. repens and F. braunii. Drought significantly reduced DMY, the most in $T$. repens (by $41.9 \%$ on average in 3 years), less in the mixture (by $24.8 \%$ ), and the least in F. braunii (by $9.6 \%$ ). Under prolonged drought conditions, gas exchange parameters of both tested species were lower than in optimally moistened treatments. Higher rate $\mathrm{P}_{\mathrm{N}}$ and $\mathrm{E}$ was shown in both species when grown in a mixture than in pure stands. The water use efficiency in $F$. braunii growing in a mixture was significantly higher in conditions of drought stress compared to pure stands, which indicates a greater stability and resistance of this species when grown in the mixture. Water deficit in the soil contributed to the increase of SPAD index in the tested species regardless of the cultivation method. We noticed that in regions with periodic water deficits, $T$. repens is more suitable for cultivation in mixture with $F$. braunii than in pure stands, due to lower yield loss and more effective physiological processes under drought conditions. 


\section{References}

Abdalla, M.M., El-Khoshiban, N.H.: The influence of water stress on growth, relative water content, photosynthetic pigments, some metabolic and hormonal contents of two Triticium aestivum cultivars. - J. appl. Sci. Res. 3: 2062-2074, 2007.

Akhtar, I., Nazir, N.: Effect of waterlogging and drought stress in plants. - Int. J. Water Resour. Environ. Sci. 2: 34-40, 2013.

Annicchiarico, P., Piano, E.: Indirect selection for root development of white clover and implications for drought tolerance. - J. Agron. Crop Sci. 190: 28-34, 2004.

Blackmer, T.M., Schepers, J.S.: Techniques for monitoring crop nitrogen status in corn. - Commun. Soil Sci. Plant Anal. 25: 1791-1800, 1994.

Blum, A.: Effective use of water (EUW) and not water-use efficiency (WUE) is the target of crop yield improvement under drought stress. - Field Crops Res. 112: 119-123, 2009.

Blum, A.: Plant Breeding for Water-Limited Environments. Springer-Verlag, New York 2011.

Caradus, J.R.: The structure and function of white clover root systems. - Adv. Agron. 43: 2-43, 1990.

Croft, H., Chen, J.M., Luo, X., Bartlett, P., Chen, B., Staebler, R.M.: Leaf chlorophyll content as a proxy for leaf photosynthetic capacity. - Global Change Biol. 23: 35133524, 2017.

Dastborhan, S., Ghassemi-Golezani, K.: Influence of seed priming and water stress on selected physiological traits of borage. - Folia hort. 27: 151-159, 2015.

Elgersma, A., Schlepers, H.: Performance of white clover perennial ryegrass mixtures under cutting. - Grass Forage Sci. 52: 134-146, 1997.

Fang, Y., Xiong, L.: General mechanisms of drought response and their application in drought resistance improvement in plants. - Cell. mol. Life Sci. 72: 673-689, 2015.

Farooq, M., Wahid, A., Kobayashi, N., Fujita, D., Basra, S.M.A.: Plant drought stress: effects, mechanisms and management. Agron. Sustain. Dev. 29: 185-212, 2009.

Flexas, J., Medrano H.: Drought-inhibition of photosynthesis in C-3 plants: stomatal and nonstomatal limitation revisited. Ann. Bot. 89: 183-189, 2002.

Frame, J., Newbould, P.: Agromony of white clover. - Adv. Agron. 41: 1-88, 1986.

Franche, C., Lindström, K., Elmerich, C.: Nitrogen-fixing bacteria associated with leguminous and non-leguminous plants. - Plant Soil 321: 35-59, 2009.

Galmés, J., Ribas-Carbó, M., Medrano, H., Flexas, J.: Rubisco activity in Mediterranean species is regulated by the chloroplast $\mathrm{CO}_{2}$ concentration under water stress. - J. exp. Bot. 62: 653-665, 2011.

Gerten, D., Rost, S.: Development and Climate Change: Climate Change Impacts on Agricultural Water Stress and Impact Mitigation Potential. - Potsdam Institute for Climate Impact Research, Potsdam 2010.

Gewin, V.: Food: an underground revolution. - Nature 466: 552553, 2010.

Golldack, D., Li, C., Mohan, H., Probst, N.: Tolerance to drought and salt stress in plants: unraveling the signaling networks. Front. Plant Sci. 5: 151, 2014.

Gray, S.B., Brady, S.M.: Plant developmental responses to climate change. - Dev. Biol. 418: 64-77, 2016.

Grieu, P., Robin, C., Guckert, A.: Sensitivity of net photosynthesis to soil drought in white clover (Trifolium repens L.). www. fao.org/docrep/V2350E/v2350e0y.htm 1993.

Hall, A.E.: Plant adaptation to hot and dry stresses in relation to horticultural plant breeding. - Adv. hort. Sci. 4: 44-48, 1990.
Hepworth, C., Doheny-Adams, T., Hunt, L., Cameron, D.D., Gray, J.E.: Manipulating stomatal density enhances drought tolerance without deleterious effect on nutrient uptake. - New Phytol. 208: 336-341, 2015.

Hura, T., Hura, K., Grzesiak, M., Rzepka A.: Effect of longterm drought stress on leaf gas exchange and fluorescence parameters in $\mathrm{C}_{3}$ and $\mathrm{C}_{4}$ plants. - Acta Physiol. Plant. 29: 103$113,2007$.

Jones, H.G.: Stomatal control of photosynthesis and transpiration. - J. exp. Bot. 49: 387-398, 1998.

Kacperska, A.: Sensor types in signal transduction pathways in plant cells responding to abiotic stressors: do they depend on stress intensity. - Physiol. Plant. 122: 159-168, 2004.

Kalaji, M.H., Łoboda, T.: Chlorophyll Fluorescence in the Studies of the Physiological Condition of Plants. - SGGW, Warsaw 2010.

Kosmala, A., Perlikowski, D., Pawłowicz, I., Rapacz, M.: Changes in the chloroplast proteome following water deficit and subsequent watering in a high-and a low-drought-tolerant genotype of Festuca arundinacea. - J. exp. Bot. 63: 61616172,2012

Kozłowski, S., Goliński, P., Golińska, B.: [Chlorophyll dyes as an indicator of the utility value of grass species and varieties]. - Zesz. Probl. Post. Nauk Rol. 474: 215-223, 2001. [In Polish]

Kura-Hotta M., Satoh K., Katoh S.: Relationship between photosynthesis and chlorophyll content during leaf senescence of rice seedlings. - Plant Cell Physiol. 28: 1321-1329, 1987.

Küchenmeister, K., Küchenmeister, F., Kayser, M., WrageMönnig, N., Isselstein, J.: Influence of drought stress on nutritive value of perennial forage legumes. - Int. J. Plant Prod. 7: 693-710, 2013.

Łabędzki, L.: Droughts and floods - a threat to agriculture. - In: Mioduszewski, W. (ed.): Water in Agricultural Landscape. Pp. 29-43. IMUZ, Water Environ Rural Areas, Falenty 2006.

Lawlor, D.W.: Limitation to photosynthesis in water-stressed leaves: stomata vs. metabolism and the role of ATP. - Ann. Bot. 89: 871-885, 2002.

Lipiec, J., Doussan, C., Nosalewicz, A., Kondracka, K.: Effect of drought and heat stresses on plant growth and yield: a review. - Int. Agrophys. 27: 463-477, 2013.

Lisar, S.Y.S., Motafakkerazad, R., Hossain, M.M., Rahman, I.M.M.: Water stress in plants: causes, effects and responses. - In: Rahman, I.M.M., Hasegawa, H. (ed.): Water Stress. Pp. 1-14. InTech, Rijeka, Croatia, 2012.

Loka, D., Harper, J., Humphreys, M., Gasior, D., Gwynn-Jones, D., Scullion, J., Doonan, J., Kingston-Smith, A., Dodd, R., Wang, J., Chadwick, D., Hill, P., Jones, D., Mills, G., Hayes, F., Robinson, D.: Impacts of abiotic stresses on the physiology and metabolism of cool-season grasses: a review. - Food Energy Security 2018: e00152, 2018.

Lu, C., Zhang, J.: The effect of water stress on photosynthesis, chlorophyll fluorescence and photoinhibition in wheat plants. - Aust. J. Plant. Physiol. 25: 883-892, 1998.

Murphy, P.M.: Growth and nitrogen fixation by white clover in rationally grazed pasture measured over three consecutive years. In: Flanagan, S. (Ed.): Proceedings of the XII Meeting of the European Grassland Federation. Pp. 292-296. Irish Grassland Association, Dublin 1988.

Olszewska, M.: Gas exchange parameters in Festulolium braunii (K. Richt.) A. Camus grown in mixtures with legumes depending on multiple nitrogen rates. - Pol. J. Natur. Sci. 23: 48-72, 2008

Østrem, L., Volden, B., Larsen, A.: Morphology, dry matter yield and phenological characters at different maturity stages of Festulolium compared with other grass species. - Acta agr. scand. B - Soil Plant Sci. 63: 531-542, 2013. 
Peng, S.Q., Liu, Y.L., Xie, S.X.: Effects of drought stress on water use efficiency and cell membrane permeability of Honeysuckle. - North. Hort. 10: 156-158, 2011.

Perlikowski, D., Augustyniak, A., Masajada, K., Skirycz, A., Soja, A.M., Michaelis, A., Wolter, G., Kosmala, A.: Structural and metabolic alterations in root system under limited water conditions in forage grasses of Lolium-Festuca complex. Plant Sci. 283: 211-223, 2019.

Perlikowski, D., Czyżniejewski, M., Marczak, Ł., Augustyniak, A., Kosmala, A.: Water deficit affects primary metabolism differently in two Lolium multiflorum/Festuca arundinacea introgression forms with a distinct capacity for photosynthesis and membrane regeneration. - Front. Plant Sci. 7: 1063, 2016.

Perlikowski D., Kosmala A., Rapacz M., Kościelniak J., Pawłowicz I., Zwierzykowski Z.: Influence of short-term drought conditions and subsequent re-watering on the physiology and proteome of Lolium multiflorum/Festuca arundinacea introgression forms with contrasting levels of tolerance to long-term drought. - Plant Biol. 16: 385-394, 2014

Saeidnia, F., Majidi, M.M., Mirlohi, A., Manafi, M.: Productivity, persistence and traits related to drought tolerance in smooth bromegrass. - Plant Breed. 136: 270-278, 2017.

Serajchi, M., Schellenberg, M.P., Mischkolz, J.M., Lamb, E.G.: Mixtures of native perennial forage species produce higher yields than monocultures in a long-term study. - Can. J. Plant Sci. 98: 633-647, 2017.

Shinoda, M., Nachinshonhor, G.U., Nemoto, M.: Impact of drought on vegetation dynamics of the Mongolian steppe: a field experiment. - J. Arid Environ. 74: 63-69, 2010.

Šimkūnas, A., Valašinaite, S., Mažeika, V.: Peculiarities of various Festulolium braunii cultivars development and overwintering. - Lžūu Mokslo Darbai 85: 35-38, 2009.

Skinner, R.H., Comas, L.H.: Root distribution of temperate forage species subjected to water and nitrogen stress. - Crop Sci. 50: 2178-2185, 2010.

Sokolovic, D., Babic, S., Radovic, J., Milenkovic, J., Lugic, Z., Andjelkovic, S., Vasic, T.: Genetic variation of root characteristics and deep root production in perennial ryegrass cultivars contrasting in field persistency. - In: Barth, S., Milbourne, D. (ed.): Breeding Strategies for Sustainable Forage and Turf Grass Improvement. Pp. 275-281. Springer, Dordrecht 2013.

Staniak, M., Kocoń, A.: Forage grasses under drought stress in condition of Poland. - Acta Physiol. Plant. 37: 116, 2015.

Staniak, M., Bojarszczuk, J., Księżak, J.: Changes in yield and gas exchange parameters in Festulolium and alfalfa grown in pure sowing and in mixture under drought stress. - Acta agr. scand. B. - Soil Plant Sci. 68: 255-263, 2018.

Staniak, M., Księżak, J., Bojarszczuk, J.: Changes in yield and gas exchange parameters in red clover (Trifolium pratense L.) and Festulolium (Festulolium braunii (K. Richt) A. Camus) under drought stress. - Appl. Ecol. environ. Res. 17: 213-230, 2019.

Stypiński, P.: The white clover research works in Poland. - In: White Clover Development in Europe, European Cooperative Research Network on Pastures and Fodder Crop Production, Series 19. Pp. 79-92. Reur Technical Series (FAO), Rome 1991.

Wilkins, R.J., Bertilsson, J., Doyle, C.J., Halling, M., Paul, C., Scholefield, D., Nousiainen, J., Syrjälä-Qvist, L.: Use of forage legumes for silage in low-input dairy production system. - Grassl. Sci. Eur. 2: 285-288, 1998. 